\title{
Development of Water Play Activities Model Based on Knowledge to Train Children Smooth Motoric
}

\author{
Riska Putri Pengarapenta \\ Postgraduate School, Universitas Negeri Medan \\ Medan, Indonesia \\ riskaputripengarapenta@gmail.com
}

\author{
Anita Yus \\ Department of Science Education \\ State University of Medan \\ Medan, Indonesia
}

\author{
Naeklan Simbolon \\ Department of Science Education \\ State University of Medan \\ Medan, Indonesia
}

\begin{abstract}
This study aims to: (1) determine the effectiveness of knowledge-based water play activities models in fine motor training for children aged 3-4 years based on indicators of children's fine motor skills and (2) to measure the feasibility of knowledge-based water play activities models in training fine motor skills children aged 3-4 years are measured based on children's play activities and the child's response to water play activities. This research method is the research and development (research and development) Borg and Gall (1987) which has the aim to develop and validate the product. Through research and development, a product of a proper and effective water play activity model was used to train fine motoric children aged 3-4 years. The results showed that children who were categorized as having fine motor skills were 21 people $(84 \%)$ while those who did not have fine motor skills were 4 people $(16 \%)$. Based on the results of this acquisition, the group (classical) can be said that the child has fine motor skills. The results of research on children's activities obtained an average percentage of children's activity at the interval of effectiveness limitation criteria, thus it can be concluded that water-based activities based on proper knowledge are used to train fine motoric children in terms of children's activities in play. The results of the research on children's responses to play activities showed that all indicators of children's response effectiveness were above $80 \%$ and thus it could be said that all aspects received positive responses from children. This means, if viewed from the child's response, the implementation of water play activities is said to be feasible to train the fine motor skills of children aged 3-4 years.
\end{abstract}

Keywords-Model Playing With The Water By Based Science, Smooth Motor

\section{INTRODUCTION}

The opportunity to obtain quality education applies to everyone (education for all), starting from early childhood as a period of "the golden age" to the level of higher education. The term "the golden age" is intended for the age of the child during his lifetime in the world, namely the age between 0 to 5 years. This age is at the best development for the child's physical and brain. Not just a matter of food, when the child is under five years old, stimulation also needs to be stimulated. The most important children are transplanted to do physical activities such as sports and play while learning. Golden age or golden phase is the phase when a child's brain experiences the fastest development during its growth [1]. Approximately $80 \%$ of the child's brain develops in this phase, so it is often referred to as the golden phase of child development. At this time, every information will be absorbed by children in the form of good information and bad information. This phase is also a basic phase to develop cognitive abilities in children as well as motor skills, socio emotional, language, religion, and moral.

Once the importance of this phase of development, children's education at an early age (PAUD) must be a concern of education stakeholders. In the National Education System Law No. 20 of 2003 Article 1 states that: "Early childhood education is a coaching effort aimed at children from birth to age 6 years which is carried out through the provision of educational stimuli to help physical and spiritual growth and development so that children have readiness to enter more education. continue ". Iskandar further revealed that: "Early childhood education does not merely function to provide learning experiences for children, but more importantly functions to optimize brain development [2]. Based on the perspective of the nature of learning and development, early childhood education is a continuous process between learning and development. That is, learning experiences and early development are the basis for the process of learning and subsequent development. Children who are at an early age get enough stimulation in developing both sides of their brains (right brain and left brain) will get a thorough preparation with success for motor learning.

Education for young children is carried out through play activities because play is a world for children that gives rise to fun and satisfaction and can develop most of their potential. Growth and development of nerve cells in children will affect the performance of the brain that will function to meet the needs of children, for example the growth and development of children's fine motor skills. Motor development in early childhood will develop optimally if you get the right stimulation. Christianti's research revealed that play activities 
are very important for early childhood because through playing the development of physical aspects of fine motor children will develop such as the ability to control eye and hand coordination, and so on [3].

Play is a vehicle for learning for children, because in addition to being a fun activity, through children's play activities can also express ideas freely in relation to the environment. Play activities can provide opportunities for children to express impulses in their fine motor systems, as well as opportunities to feel objects and challenges to find things in new ways, but to achieve these goals (training fine motor skills), it is needed the intensity of the game is good and quality. The same thing was also expressed by Moeslichatoen who said that through games, children get lessons that contain aspects of cognitive, social, emotional and physical development. With various forms of children's games designed to develop well. Through play activities, the child's brain will be transposed through activities carried out such as seeing, hearing, touching and feeling everything [4]

Stages of child development can also be a feature in children's play activities, so that play activities can be predicted and used as a reference in children's development. When the importance of play can be understood by educators, educators can make play activities more important in learning activities for children. Creating an atmosphere of teaching and learning activities that are fun and meaningful for children is very important and needs to be done as an effort to train the fine motor children in PAUD Play activities provide opportunities for children to absorb some material. Therefore, the need for interesting play activities is useful to build a happy atmosphere and can help children understand the subject matter that will be delivered by the teacher. Interesting play activities will create an atmosphere of learning to practice children's motor skills.

Motor development is the development of controlling physical movements through coordinated nerve center, nerve and muscle activities [5]. Motor development includes the development of gross motor and fine motor. Coarse motor is a movement that uses large muscles such as walking, running, jumping, etc., while fine motor is a movement that uses fine muscles such as writing, folding, cutting, stirring, mixing, mixing, etc. [6].

Play activities carried out by children are often dominated by activities that aim to develop gross motor aspects, for example: running, playing bicycle, chasing, jumping, climbing, slipping, and so forth. This happens because in general a lot of activities related to gross motor can be done without using tools or game media. For example walking, running, and jumping. This activity is often done by children while playing at home or at school with their peers. Meanwhile activities aimed at developing the fine motoric aspects of children generally have to use tools or play media. For example, cutting activities can only be done when there are scissors and materials to cut, stirring activities can be done when there are stirring tools and materials to be stirred, and so forth. This has become one of the causes of the implementation of activities aimed at improving the fine motor aspects of children who tend to and are often overlooked and can even be said to be rarely done by children.

The purpose of this study was to determine the effectiveness of water-based learning activities models in training fine motor skills of children aged 3-4 years.

Motor comes from the word "motor" which is a biological or mechanical basis that causes a motion (gallahue). In other words, motion (movement) is the culmination of an action based on the process of motor movement.

Motor development is physical development through coordinated nerve center, nerve, and muscle activities. The motion comes from the development of reflexes and activities that have existed since birth. Thus before the development of motor movement begins to process, it will remain helpless [7].

Motor development can be defined as a change in competence or ability to move from infancy to adulthood and involve various aspects of behavior that exist in humans affect motor development and motor development itself affects human abilities and behavior [8].

One of the abilities that need to be developed in early childhood education is motor development, because Christianti's research has proven that play activities are very important for early childhood because through playing the development of physical aspects of fine motor children will develop, including the ability to control eye and hand coordination, and others [3].

Motor skills take place through several stages, Robb divides into several stages, namely: (1) the stage of forming the plan, (2) the training phase, (3) the implementation phase [9], and Schmidt quotes the opinion of Fitts and Postner who state that learning motor skills takes place through several phases, namely: (1) the cognitive phase, (2) the fixation phase (association), and (3) the automation phase [10]. Motor learning consists of the stages of mastery, refinement and stabilization of motor or sports technical skills [11].

Stages of children's development can be a hallmark in children's play activities, so play activities can be predicted and used as a reference in children's development. When the importance of play can be understood by educators, educators can make play activities more important in learning activities for children. Motor development means the control of physical movement through coordinated nerve center, nerve and muscle activities [12]. Whereas fine motor is a movement that uses fine muscles or certain parts of the body, which is influenced by the opportunity to learn and practice. Then the motor skills are very important so that children can develop optimally. The ability of children to play their fingers is a motor foundation that is beneficial for the development of hand muscles. Fine motor development skills are still rolling until brain development is the basis for a child's cognitive development. Because every movement made by a child is controlled by the brain, so the more often the freedom is given to move and practice the fine motor skills of the child, the right-left hemisphere of the brain is more directed in developing children's creativity and imagination. 


\section{RESEARCH METHODS}

The method used in this research is research and development. In the research and development method there are several types of models. The model used is the development of the Borg and Gall model which has the aim to develop and validate the product [13]. The model of the development has the following steps: (1) research and information gathering, (2) planning, (3) product development, (4) initial testing, (5) major product revisions, (6) further field tests, (7) revised operational production, (8) operational field tests, (9) final field tests, and (10) dissemination and implementation.

Through this research and development, researchers are trying to develop products that are appropriate and effective water play activities used to train fine motor children aged 3-4 years. The product developed in this study is a knowledgebased interactive play model where children do active activities doing many things to gain experience to practice their fine motor skills.

\section{RESULT AND DISCUSSION}

The product of this research is a model of knowledgebased water play activities to train fine and effective motor skills of children aged 3-4 years. In the process of developing to get an effective knowledge-based play activity model, a play book model and related research instruments were compiled.

The results showed that 1 person $(4.00 \%)$ had fine motor skills that were not good, children who had poor motor skills were 3 people (12\%), 16 people $(64 \%)$ had good enough abilities $(64 \%)$, children who have fine motor skills categorized as good 3 people (12\%), and children who have fine motor skills very well as many as 2 people (8\%).

Based on the results of data analysis about children's fine motor skills as shown that there are 1 person $(4.00 \%)$ of children who have fine motor skills are not good, children who have fine motor skills are not good 3 people (12\%), children who have sufficient ability good 16 people $(64 \%)$, children who have fine motor skills in the good category 3 people $(12 \%)$, and children who have fine motor skills very well as many as 2 people (8\%).

Based on the criteria for classifying the fine motor abilities of children, children who are categorized as having fine motor abilities in children are 21 out of 25 observed children or $84 \%$ while those who do not have fine motor skills are 4 people $(16 \%)$. Based on the results of this acquisition, as a group (classical) it can be said that the child already has fine motor skills. Thus it is concluded that the knowledge-based water play activities carried out can improve the fine motor skills of children aged 3 to 4 years in PAUD Bharlind School Medan 2018/2019 Academic Year.

The results of this study are in line with the findings of a study conducted by Kamariah which also concluded that children are able to develop fine motor skills through the cooking class game model given [14]. Knowledge-based water play activities involve many activities related to children's fine motor development. Through water play activities, children are increasingly motivated to make movements that require smooth muscle coordination such as: pushing, lifting, squeezing, and throwing.

Playing children who are less creative and innovative such as coloring which is often done in PAUD schools will not develop children's fine motor skills to the fullest, because these activities involve little movement of smooth muscles [15]. In contrast to the knowledge-based water play activities carried out in this study, the water play activities carried out besides being a new play activity for children, this water play activity is also more innovative and creative. The selected tools and play materials are based on knowledge, with the aim of not only the fine motor skills of the child to be improved but also through water games, the child's knowledge will increase.

\section{CONCLUSION}

Based on data analysis and research discussion, it can be concluded that the knowledge-based water play activity model is effective for training fine motor skills of children aged 3-4 years.

Based on the results of the study and conclusions provide suggestions for the knowledge-based water play activity model produced in this study can be used by teachers to train fine motor skills of children aged 3-4 years but it is possible to use a model of play activities that use non-water material.

\section{ACKNOWLEDGMENT}

The author would like to thank the parties involved in this research. The author hopes this research can be useful for researchers who will conduct research on the same topic.

\section{REFERENCES}

[1] Rosidi A, \& S.A., 2012. Optimalisasi Perkembangan Motorik Kasar dan Ukura Antropometri Anak Balita di Posyandu "Balitaku Sayang" Kelurahan Jangli Kecamatan Tembalang Kota Semarang.

[2] N Tientje dan Yul Iskandar, PAUD Untuk Mengembangkan Multiple Intelegensi, Darma Graha Press, Jakarta, 2004.

[3] Martha Christianti. 2007. Anak Bermain. Jurnal Club Prodi PGTK UNY, 1-8.

[4] Moeslichatoen R. 2004. Metode Pengajaran Di Taman Kanak -Kanak. Jakarta: PT Asdi Mahasatya.

[5] Hurlock, E. B, Perkembangan Anak Jilid 1 Edisi Keenam. Alih Bahasa:Meitasari Tjandrasa. Jakarta:Penerbit Erlangga, 1978.

[6] Suyanto, Konsep Dasar Anak Usia Dini. Jakarta : Departemen Pendidikan Nasional, 2005.

[7] Hurlock, E. B, Perkembangan Anak Jilid 1 Edisi Keenam. Alih Bahasa:Meitasari Tjandrasa. Jakarta:Penerbit Erlangga, 1978.

[8] Payne, E.F. K.L. Bruce,andW.T. Kert. 1990. Reservoir Limnology :Ecological Perspectives. John Wiley \& Sons, Inc. Kanada.

[9] Robb, Margaret D. 1972. The Dynamics Of Motor Skill Acquisition. New Jersey: Prentice Hall, Inc.

[10] Schmidt, Richard, A. 1988. Motor Control And Learning. Second Edition. Illinois: Human Kineticks Publisher Inc.

[11] Merril M.David and, Robert 0,(1977). Teaching Concept: An Instructional Design Guide, New Jersey: Englewood Cliffs. 
[12] Lutan, Rusli. 1988. Belajar Keterampilan Motorik Pengantar Teori Dan Metode. Jakarta: P2LPTK Ditjen Dikti Depdikbud.

[13] Hurlock, Elizabeth B. 2011. Psikologi Perkembangan : Suatu Pendekatan Sepanjang Rentang Kehidupan. Jakarta : Erlangga.
[14] Borg \& Gall. 2003. Educational Research-An Introduction. London : Longman.

[15] Pertiwi kamariah. 2018. Pengemabngan Model Permainan Cooking Class Untuk Meningkatkan Motorik Halus Anak Usia Dini Di Taman Kanak-Kanak Yapi Jaya Makasar. Jurnal Pascasarjana Unimed. 